Vol. 6, No. 1, 2020

УДК 096.44+730-032.5

Olena Stasyuk

\title{
CEMETERY AND CHURCH: ART ENVIRONMENT AND SPIRITUALY-FUNCTIONAL SYMBIOSIS
}

\author{
Lviv Polytechnic National University, AR Department \\ Lviv Polytechnic National University, Lviv \\ Ph.D architecture \\ e-mail: olena.stasyuk@gmail.com \\ orcid: 0000-0002-2986-6321
}

Received: 27.05.2020 / Revised: 10.06.2020 / Accepted: 10.06.2020

(C) Stasyuk O., 2020

https://doi.org/10.23939/as2020.01.018

\begin{abstract}
The article is studying the role and place of art in shaping the spiritual and functional space of the cemetery and the church in the conditions of moral and religious chaos. The study is based on the study of historical monuments and newly built church complexes in Galicia. In particular, the dynamics of the coexistence of church and cemetery in large cities, as well as in historic towns and villages are considered.
\end{abstract}

Key words: cemetery, church, works of art, monument, conservation.

\section{Problem statement}

Christianity is the largest religion in Europe. After the adoption of Christianity by the Roman emperor Constantine, Europe became an important center of Christian culture. The occurrence of the concept "Europe" is closely related to the concept of "Christianity" or "Christian world". At all times, traditions of folk religion have existed largely regardless of official denominations or dogmas. Christianity in Ukraine is a national religion. The Church is regarded by Christians as the most important and necessary institution of Christianity. In Ukraine, the church appears not only as an institution, a community of believers and priests but also as a temple in which Christian worship takes place. For the Ukrainians, the temple itself is extremely important - it is the manifestation, the material embodiment of the spiritual essence of Christianity. This is the house of God, and most churches are not ordinary buildings, but real works of art. In ancient times the area around each Christian temple was also called a "cemetery". The cemetery was a place where the bodies of the dead were resting in peace, awaiting the time of the Second Coming of the Lord and the general resurrection of the dead. In ancient times, Christians were buried around churches, as well as in church crypts and vice versa temples and chapels were specially built in places of mass graves. Thus, the interaction and coexistence of memory of the past, the realities of the present, and the hope of the future.

\section{The purpose of the article}

The purpose of the article is to find out the role of the spiritual and artistic environment and the place of the functional space of the cemetery and the church in the modern world, the prospects of their preservation and coexistence. 


\section{Analysis of recent research and publications}

The historical cemeteries of Ukraine in general and, in particular, Galicia are poorly researched. Existing research mainly relates to the history of origin and describes the outstanding people buried in these cemeteries. Mostly addressed to the known cemeteries in major cities. The history of church architecture has been studied by many scholars, historians, architects, and art critics in particular M. Drahan, V. Aleksandrovych, V. Slobodian, J. Taras, and others. A church and a cemetery are generally studied by different people separately and from different perspectives. The issues of memorial plastic, both professional and folk, were in one way or another raised by the researchers M. Mozdyr, I. Mohytych, I. Kryp'iakevych, A. Dorosh, R. Odrekhivskyi, K. Prysiazhnyi, J Biriulov, and others. Questions of Galicia historical cemeteries are explored by M. Dolynska, A Chemerchynskyi, P. Hrankin, H. Kharchuk, and others.

\section{Result and discussions}

Lviv is an ancient and historic city the oldest part of which is listed on the UNESCO World Heritage List.

Speaking about such a city as Lviv is, we usually talk about history. This history is multicultural, dynamic, constantly changing, and vividly reflected in architecture. The architectural history of Lviv is largely shaped by Christian temples. The first written mention of Lviv happens in the Galicia-Volyn chronicle, so 1256 is the official date of Lviv's founding. Although the exact date of the foundation of the city and its founder is still debatable. The current main square is the Rynok Square, which is the center of what is now an existing historic city, was founded south of High Castle based on a privilege received from King Casimir III (Krypyakevych, 1991, s. 10-15). The Rynok Square is still the heart of the old city of Lviv and this is the part that is on the UNESCO World Heritage List. Quarters around Rynok Square are formed by four national communities of Lviv - Ukrainian, Polish, Armenian and Jewish. The architectural face of each of the communities is most clearly manifested in the place of worship. In ancient times a cemetery existed around each of the churches. This tradition was stopped by the reforms of the Austrian Emperor Joseph II on the elimination of cemeteries around the church in the cities. And then four new cemeteries were laid in Lviv outside the city. Let us see what is happening in Lviv today. The oldest temples of Lviv are traditionally considered to be the Church of St. Nicholas and the Church of John the Baptist. Church of St. Nicholas is a temple of white hewn stone, raised near the foot of Prince's Mountain. There is a historical tradition according to which the church was a courtier for the Galicia-Volyn princes, a princely tomb, and the center of the social and political life of early Lviv (Zubryczkyj, 1845, s. 15-18). The Church of John the Baptist was also built near the foot of Prince's Mountain. There are no accurate, scientifically proven data on the foundation and ancient history of the temple. At different times, several hypotheses were put forward that offered a wide range of origins and dates for the construction of the building, varying from 1201 to 1370 years. The most popular is the legend that the temple was built around 1260 by the Prince of Galicia-Volyn Lev I for his wife - the Hungarian Princess Constance, daughter of King Bela IV (Kachor, 2004, s. 168-169). Today we can not see any traces of the cemetery around these ancient churches. If we talk about the church of St. Nicholas as a prince's tomb, then the burial should be sought in crypts.

As for the quarters around Rynok Square. The Ukrainian quarter is marked by the Assumption Church whose ensemble includes its church, bell tower, and chapel. It is the most interesting monument of the Lviv Renaissance, built in the years 1591-1629 by the order of the Lviv Stavropigian brotherhood. The brotherhood organized a hospital and a cripple shelter in Lviv, had a printing house, a school, and led its own library (Mogytych, 1982, s. 14-17). As for burials, today we can only talk about burial in the crypt of the church. No other traces of the cemetery are preserved.

The Polish Quarter is marked by the Latin Cathedral as the main Lviv temple of the Roman Catholic Church. According to one version, the cornerstone of the Cathedral was laid in 1349 by King Casimir III. During history, Cathedral has been repeatedly rebuilt and reconstructed. Nowadays, 8 chapels remained, which are built around the temple. From the very beginning, there was a cemetery around the Cathedral. Probably it 
arose around 1405 when the cathedral was consecrated because no one was buried in the unholy land. The cemetery occupied the territory of almost all of the present Cathedral Square and was enclosed by a wall. On the wall, there was a large gate and three wickets.

In 1776 the walls of the cemetery were demolished. At the same time, the sculpture group "Christ on the deathbed" (also known as the "The Tomb of the Lord" chapel), standing in one of the gates, was brought under the cathedral walls (Kozubska, 2000, s. 252-261). After the so-called "Josephine" reforms, the cemetery was eliminated. Of the six chapels standing alone, only the Boim Chapel is preserved. Some statues of saints were also preserved. After the demolition of the cemetery, these statues were put on the wall around the cathedral. The Chapel "The Tomb of the Lord" can be still seen today near the south wall of the cathedral. (Fig. 1)

The Armenian quarter is marked by an Armenian church whose ensemble includes a bell tower, a palace of the Armenian archbishops, an Armenian bank, a monastery of Armenian Benedictines. All the buildings are clustered around the church, forming three small enclosed courtyards. In the yards, you can view the remains of the Armenian cemetery. These are tombstones, traditional for Armenians. The oldest tombstones are about 600 years old. They were moved from the cemeteries of other Armenian temples and monasteries that have not existed in Lviv for several centuries. On the walls, you can see ancient epitaphs written in Latin. Among them: "This is the tomb of the Reverend Father Patriarch of Greater Armenia, who was in Rome and on his way to Lviv gave his soul to God in the year of God in 1551"; "The Earth to Earth, the Soul to God was given by Ignatius Nurovich in 1769” (Krypyakevych, 1991, s. 74-75).

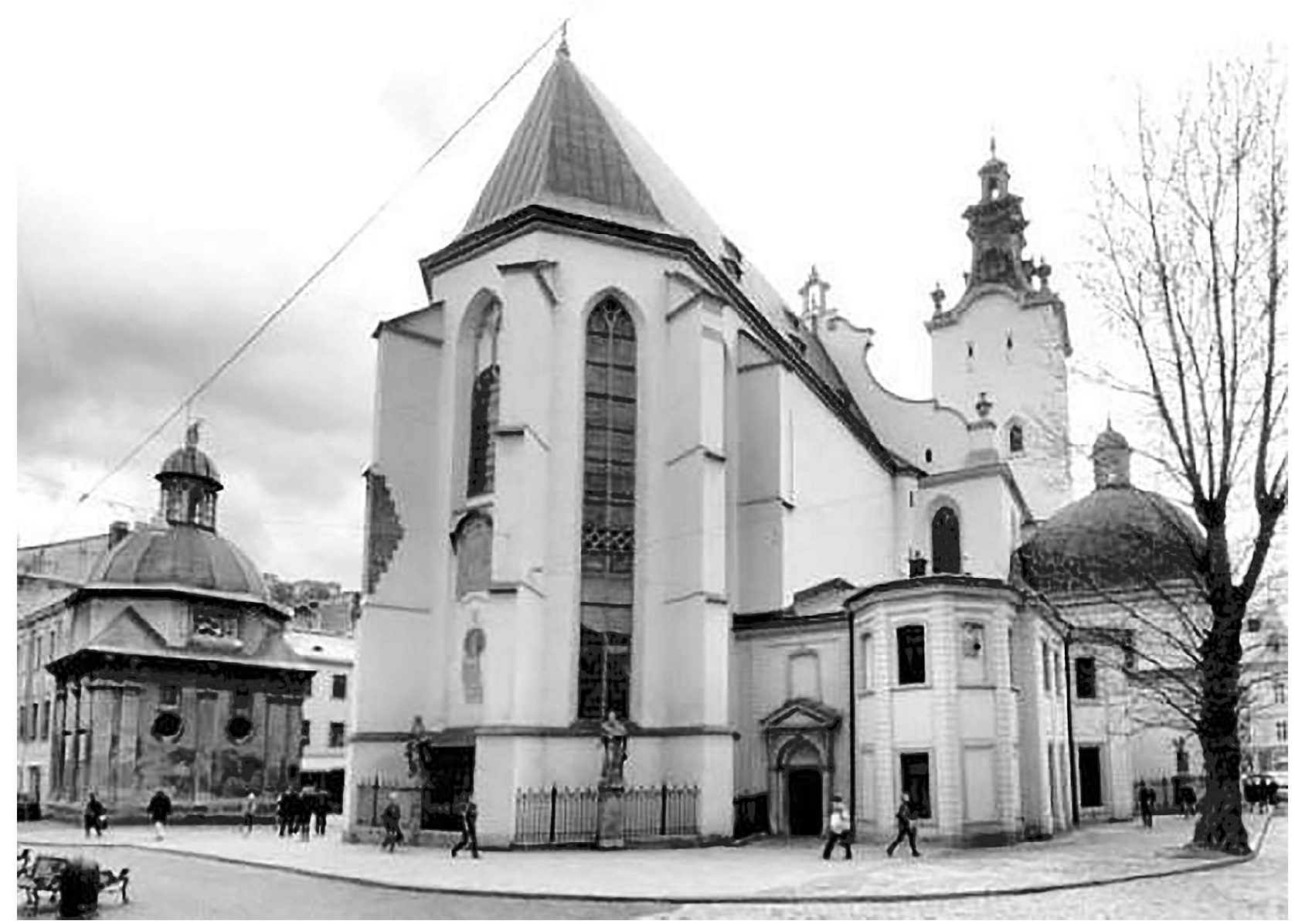

Fig. 1. Latin Cathedral and the Boim Chapel

All Christian temples of all national communities have been preserved to this day and are in operation. In addition, in the old city, the so-called city on the walls, there were a number of monasteries with their temples. 
These temples today are active and occupy an important place in the architectural face of the city. These include the complex of the Jesuit temple and monastery (today Saints Peter and Paul Garrison Church), the complex of the Dominican temple and monastery (today the Church of the Holy Eucharist), the complex of the temple and monastery of Carmelites (today the Church of St. Michael). There were no cemeteries around any of these temples. Crypt burials, tombstones, and tables inside temples have been preserved. The complex of the temple and the monastery of Bernardine (today St. Andrew's Church) can be considered as an exception and interesting thing. The wooden monastery was built in the 15 th century on the site of the modern building. In the $1600 \mathrm{~s}$ and 1630 s, a stone temple and the whole monastery complex was constructed with stone. It was stone walls with loopholes and a tower; outbuildings, forge, stable, cemetery. In 1484, St. John of Dukley was buried there. According to legend, a healing source soon appeared at the burial site. A well with a stone rotunda was built above the source. The relics of the saint were moved to the temple, where they are kept to this day (Vecherskyj, 2008, s. 335-337). In honor of Blessed John of Dukley, a column with the figure of a saint was built near the church. We can still see the column today, it is topped with a flowerpot. The figure was moved to a stone rotunda above a well near the north side of the temple.

Today, about a hundred churches of different denominations operate in Lviv. The oldest churches are concentrated in the historic center of Lviv. The rest churches are very different: they were built in the 18th and in the 19th, at the beginning of the 20th, and at the end of the 20th century. Today, there are 13 cemeteries in Lviv, of which four are active. Nowadays, in Lviv there is not a single cemetery around the church: neither acting nor out of use. We can only study the history and see the remains or traces of former cemeteries around the Latin Cathedral, the Bernardine Church, and the Armenian Church. The Armenian tombstones are absolutely original with their own inscriptions, images, compositions. Not similar to other Christian tombstones we may see in Lviv. The existing Bernardine church is built in a baroque style. All of its interior decorations are made in the same baroque style. The preserved elements of the former cemetery, the column itself, and a stone rotunda with a well and the sculpture of St. John is designed in the same baroque style.

I is a pity that only one chapel has been preserved from the detached ones around the Latin Cathedral. The preserved Boim's Chapel is a true masterpiece, a pearl of Renaissance architecture in Lviv. If the other chapels in their artistic qualities were at least half as preserved, their disappearance is a great loss for Lviv. The second reminder of the nonexistent cemetery is the baroque figures of the saints on the wall around the cathedral. The Latin Cathedral has a long and rich history. It has been rebuilt and reconstructed many times. In particular, during the Baroque period, the Cathedral received baroque tops, decorative flowerpots in the exterior and some interior decoration: paintings, sculptures, etc. The baroque sculptures around the cathedral fit quite organically into the exterior of the building.

On the preserved remains we can only hypothesize how did these churchyard cemeteries look. From what we see, the idea is that these are the same architects and artists who built the church and chapels, and then the same sculptors performed the building of the church, chapel, and tombstones for the cemetery. The successor to the churchyard cemeteries is probably the Lychakiv Cemetery, which was opened in 1786. In the Lychakiv Cemetery well-to-do, mostly noble families also built monumental chapels, mostly in the new style. 24 chapels have been preserved there. About 500 sculptures and reliefs are constructed on the graves and tombs in Lychakiv. Famous architects and sculptors, authors of many other buildings, and structures in Lviv worked at Lychakiv Cemetery (Harchuk, 2013, s. 232-239).

There is no church built at Lychakiv Cemetery. There is no church in any of the existing cemeteries in Lviv. You might think that the tradition of coexistence between the church and the cemetery is interrupted. But this is not quite so. If we will leave Lviv and go along the highway, whether in the western or the eastern directions, every time we can see a church in small villages, and the cemetery near it. In bigger towns, the situation is that if the church is located in the town center, there is usually no cemetery around. There may be several old crosses around the church, a monumental or patrimonial cross, or something like a cross on a mass grave. If the church is located near the edge of town, there already appears cemetery.

The city of Kolomyia is a very good example. Kolomyia has been known since the mid-13th century as a salt extraction center. It suffered considerable destruction during the Turkish-Tatar attacks in the 16th-17th centuries. Nowadays, Kolomyia is the district center of the Ivano-Frankivsk region. The Kolomyia City Ritual 
Service oversees one active and two inactive cemeteries. The cemetery on "Monastyrok", or so-called Ukrainian, is located at Carpathian street. Burial in the cemetery began in the first half of the 19th century. Immediately at the entrance to the cemetery, to the left of the main alley, stands the wooden Church of the Annunciation and the bell tower. The people called it "monastery church", because in ancient times, according to legend, there was a monastery near the church. A similar name was given to the cemetery. The church was built in 1709. This date has been preserved on the sill of the south door of the porch of the modern building. In 1980, the church was restored. Since 1983, Easter Egg Painting Museum has been opened in the church building (Slobodyan, 2009, s. 62-67). Today the church is active but the cemetery is not active anymore (Fig. 2). In this case, the church and the cemetery have nothing to do with each other. The church is a wonderful example of folk wood architecture. And the cemetery is a testament to the fact that in the 19th century Kolomyia was a highly developed, rich, European city, part of the Austrian Empire. The cemetery is urban: it is a large area divided by alleys. Alleyways are paved: they are not dirt roads and paths but paved alleys. The graves and the tombs are arranged in orderly and clear rows. The tombs and tombstones are made by professional architects and sculptors. The scale and capacity of the cemetery are also reflected in the palette of materials from which the monuments were made. It is diverse and rich - you can see not only the local material but also the material brought from afar, such as marble. Cemetery with a church surrounded by a wall, there are entrance gates and wickets. In simple terms, this is like the Lychakiv cemetery, just a little bit smaller.

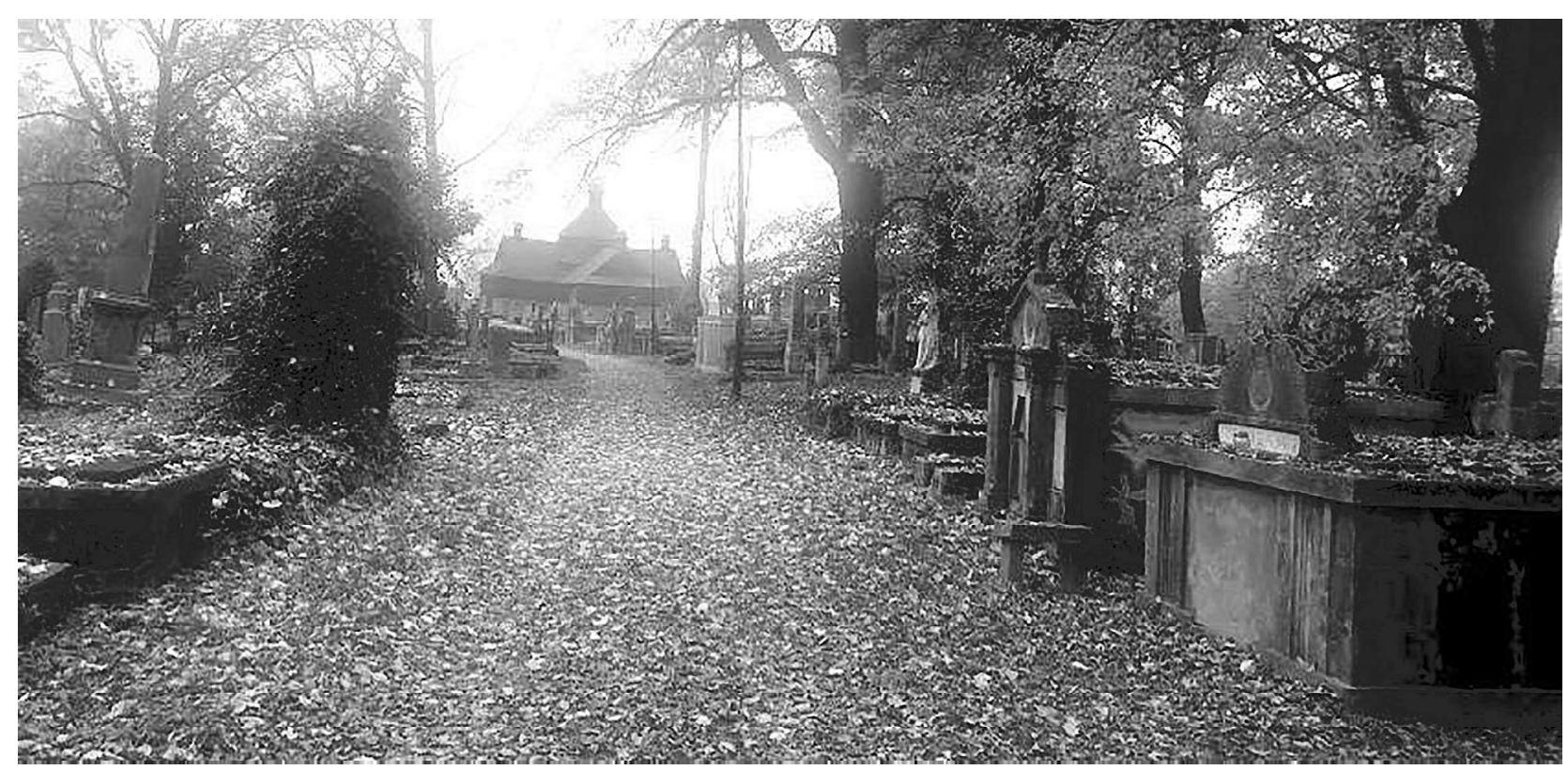

Fig. 2. The cemetery on "Monastyrok" in Kolomyia

Another example provided is the city of Rohatyn. Rohatyn arose at the settlement site of the Slavic tribes. The first written mention of Rohatyn dated 1184 when the settlement was part of the Galicia-Volyn principality (Grushevskyj, 1913, s. 229). Nowadays, Rohatyn is a district center of the Ivano-Frankivsk region. There are five Christian temples in the city. Among them, the Church of the Holy Spirit - the oldest preserved wooden church in Ukraine. It is dated 1598 - this date was found in the interior of the church on the north wall of the central $\log$ house (Slobodyan, 2004, s. 142-147). In June 2013, the Church of the Holy Spirit, together with other wooden churches of the Carpathian region, was included in the UNESCO World Heritage List. The other end of Rohatyn houses the wooden church of St. Nicholas, which was constructed in 1729 (Slobodyan, 2004, s. 150-154). The church is located on a picturesque hill. Near the church of St. Nicholas in the west direction is a bell tower. The cemetery with old interesting tombstones is located around each of these wooden churches (Fig. 3). Both wooden churches are examples of folk architecture. The cemeteries around them are formed by limestone tombstones dominated by the cross motif. There are several figures near the Church of the Holy Spirit. All the tombstones are made in the folk style by true local craftsmen. 


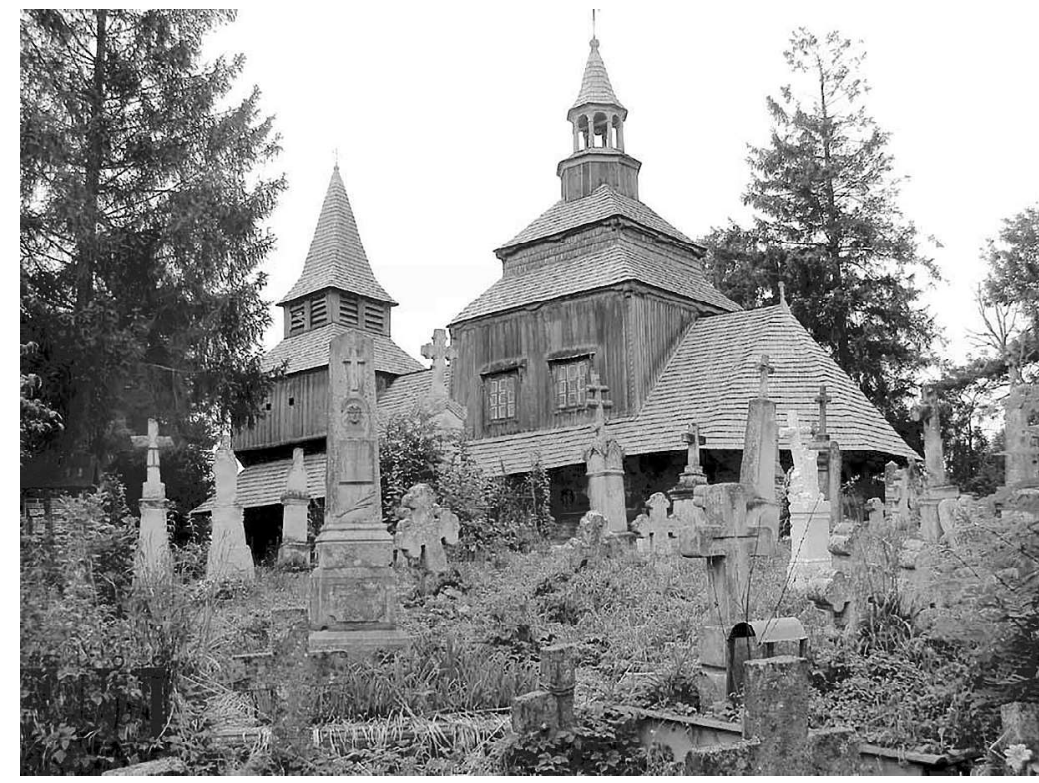

Fig. 3a. The Church of the Holy Spirit in Rohatyn

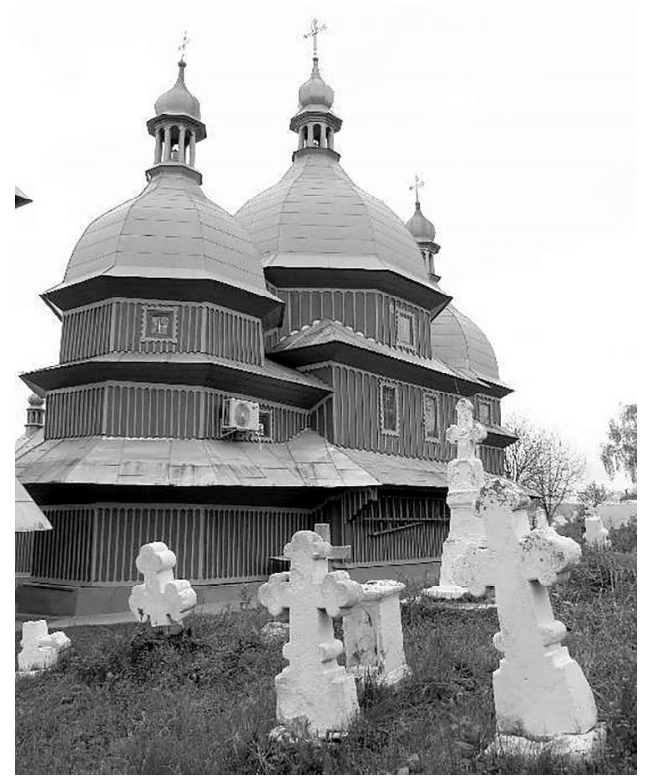

Fig. 3b. The Church of St. Nicholas in Rohatyn

Finally, the village of Smolin (Yavoriv district, Lviv region). In the 15th century, it was a large village (firstly mentioned in the massif of the written documents in 1423). At that time there was an independent parish of the Eastern rite in the village. The present Church of the Transfiguration stands on the site of several previous Orthodox churches, built in 1753 from the foundation of the village community (Shematyzm, 1939, s. 83). The church is bordered by a cemetery with tombstones of the Brusnian stone masonry school (Fig. 4). This is an extremely typical example of the coexistence of a church and cemetery in a small village in Galicia. We can gather huge numbers of such examples. The photograph taken from the window of the car by the roads of Galicia is extremely demonstrative, visual, and illustrative (Fig. 5).

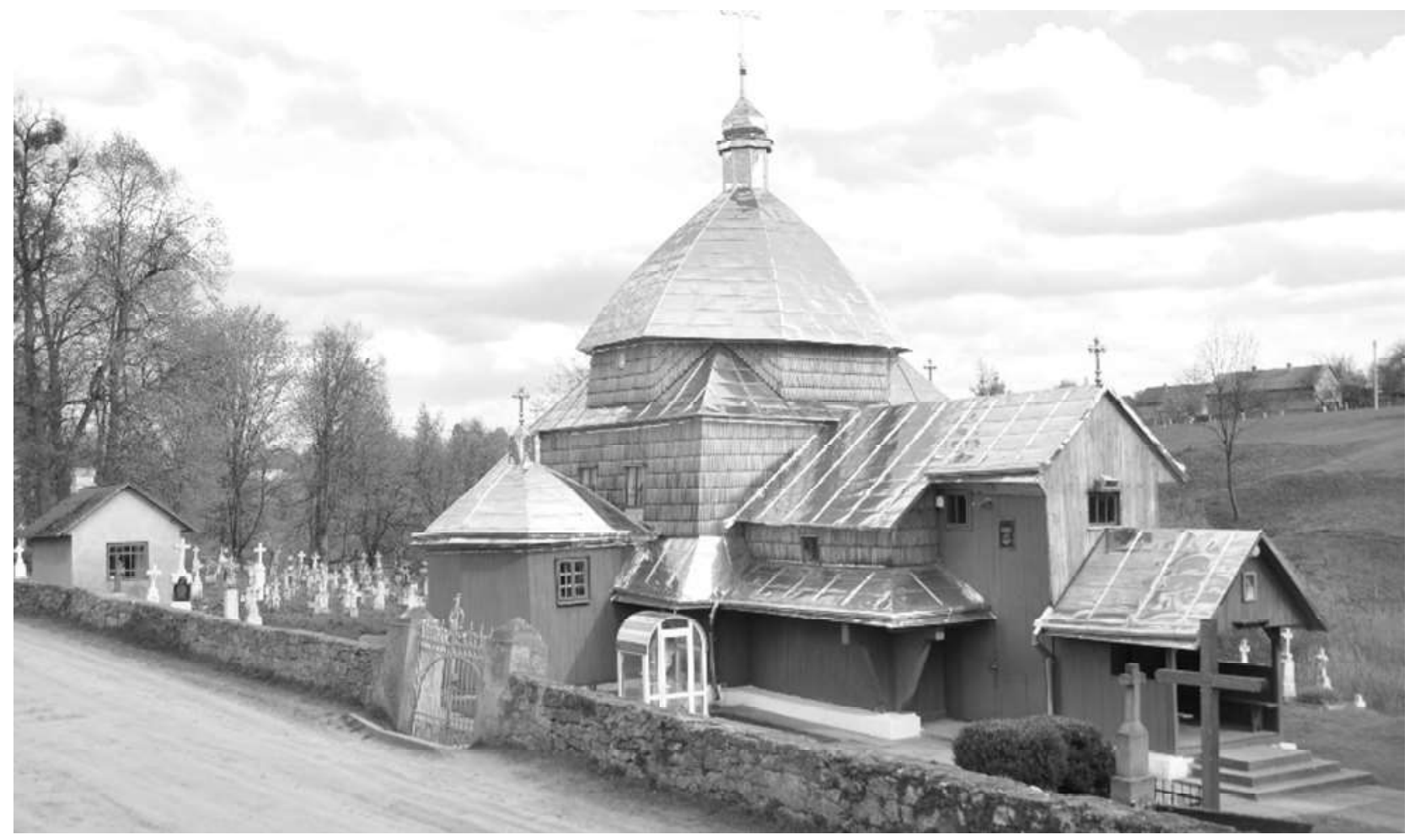

Fig. 4. The church and the cemetery in Smolin 


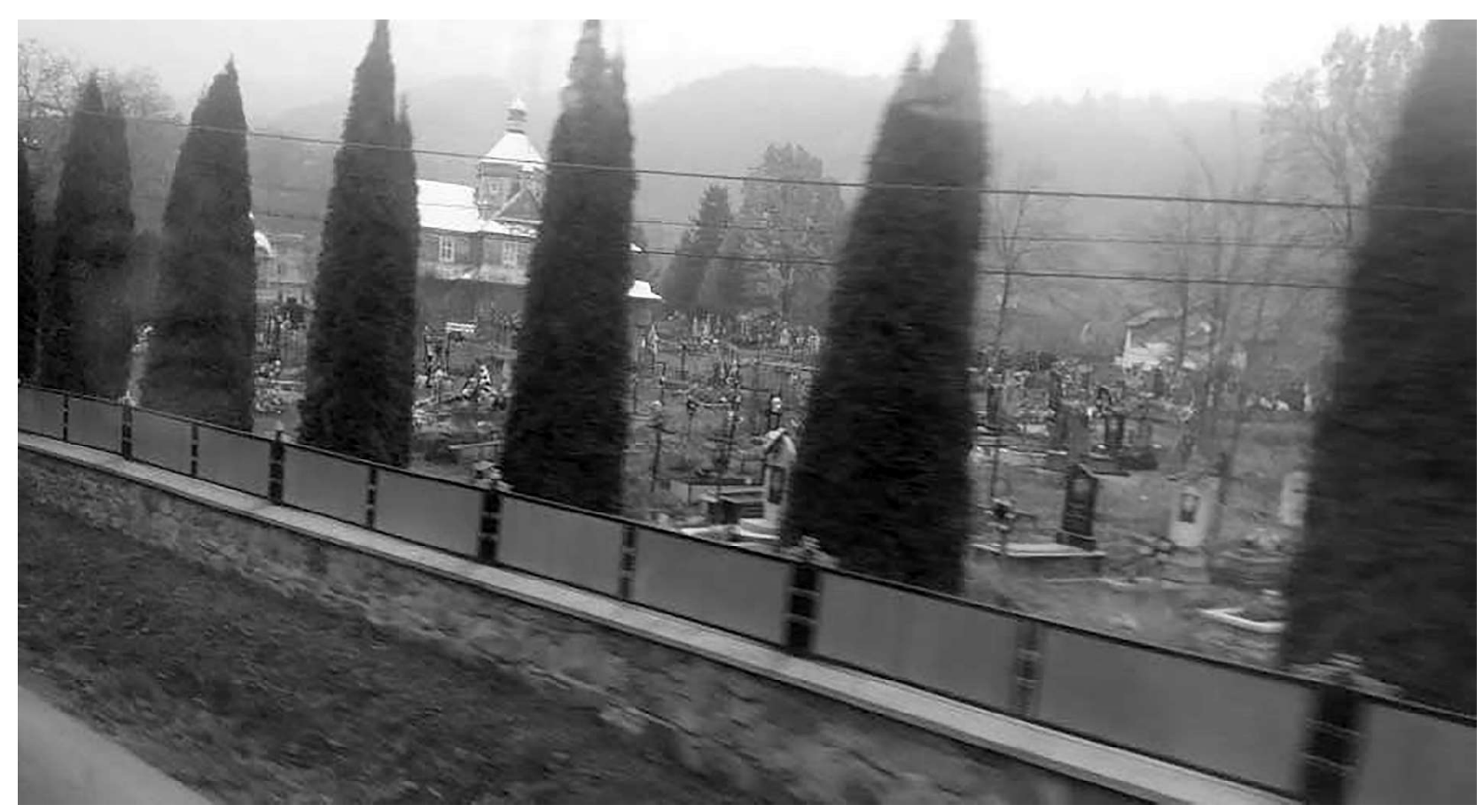

Fig. 5. The church and the cemetery. Photo by the roads of Galicia

\section{Conclusions}

And those historic churches and those newly built churches in Galicia are real works of art. And the number of newly built temples is astounding. The spiritual environment is not thought without the artistic environment. The church is the material embodiment of the spiritual environment which is improved and decorated with the use of all available artistic means. And this has not changed since the Middle Ages until today.

The coexistence of the cemetery and the church has been very close for centuries. "Mini-cemetery" in church crypts and a real cemetery around the church. Today, this situation has changed dramatically.

The example of laying a cemetery around a newly built church was not found. The actual construction of a church in a newly laid cemetery or in a relatively new cemetery that is functioning and has no church was not found, too. That is to say, today the church and the cemetery are moving in the direction of coexistence at a distance.

This situation characterizes larger cities: more dynamic, rapidly evolving, and changing. Small towns and villages are more likely to preserve traditions. If there is a cemetery near a church in some settlement, today nobody is going to destroy it. Nowadays, people are more respectful of the cemetery and the church, not only as an institution but as a building, too.

\section{References}

Grushevskyj, M. (1913) History of Ukraine-Rus. Kyiv, T. 5, 229-243.

Harchuk, H. (2013). Forming of Lychakiv necropolis in Lviv (17th - 20th centuries). Bulletin of the Lviv Commercial Academy. Series: Humanities, 11, 232-239.

Kachor, I., Kachor, L. (2004). Lviv through the ages. - Lviv: Center of Europe.

Kozubska, O. (2000). Latin Cathedral in Lviv: An attempt at a new interpretation of known facts. National Notebooks., 2, 252-261.

Krypyakevych, I. (1991). Historical walkways in Lviv. Lviv: Stonemason.

Mogytych, R. (1982). The ensemble of Ruska street. Lviv: Stonemason.

Schematism of the Greek Catholic clergy of the combined dioceses of Peremyshka, Sambir and Sianitskaya for the year of God in 1939. Przemysl, circulation of the Greek-Catholic Episcopal Consestory,

Slobodyan, V. (2004). Temples of the Rohatyn region. Lviv: Logos. 
Slobodyan, V. (2009). To the History of the Church of the Annunciation The Virgin Mary in Kolomyia. Bulletin of Ukrzakhidproject restoration,19. L`viv, 62-67.

Vecherskyj, V. (2008). Ukrainian monasteries. K., Kharkiv: TzOV "Information and Analytical Agency "Our Time" "“Globus" Book Factory, Kharkiv".

Zubryczkyj, D. (1845). Critical-historical Tale of the Bygone Years of Chervona or Galician Rus. From the introduction of Christianity under the princes of the generation of Vladimir the Great to the end of the 15th century

\section{Олена Стасюк}

кафедра архітектури та реставраиії, доктор архітектури, Начіональний університет "Львівська політехніка", Львів кандидат архітектури

e-mail: olena.stasyuk@gmail.com

orcid: 0000-0002-2986-6321

\section{ЦВИНТАР І ЦЕРКВА: МИСТЕЦЬКЕ СЕРЕДОВИЩЕ ТА ДУХОВНО-ФУНКЦІОНАЛЬНИЙ СИМБІОЗ}

Анотація. Християнство - найбільша релігія в Свропі. Після прийняття християнства римським імператором Костянтином Свропа стала важливим иентром християнської культури, Виникнення поняття "Свропа" тісно пов'язане з поняттям “християнства” чи “християнського світу”. У всі часи традиџї народної релігії існували в значній мірі незалежно від офіщійних конфесій чи догматів. Християнство в Україні є справді народною релігією. Церкву християни розглядають як найважливіший та необхідний інститут християнства. В Україні иерква фігурує не лише як інститучія, спільнота віруючих мирян і священників, але і як храм, в якому відбувається християнське богослужіння. Для україниів сам храм є надзвичайно важливим - це унаочнення, матеріальне втілення духовної сутності християнства. Це дім Бога, а більшість церков - це не звичайні споруди, а справжні витвори мистеутва. Територію навколо кожного християнського храму називали також $і$ “ивинтарем”. Цвинтар був місием де тіла покійних спочивають, очікуючи часу Другого пришестя Господнього та загального воскресіння померлих. У давнину християн ховали довкола церков, а також в иерковних криптах. I навпаки - храми та каплиі спеціально будували на місиях масових поховань. Звідси властиво взаємодія і співіснування пам'яті минулого, реалій сьогоднімнього і надії на майбутнє.

Сьогодні у Львові функиіонуе біля сотні церков різних конфесій. Найстаріші иеркви зосереджені в історичному центрі Львова. А далі церкви є дуже різні - побудовані і у XVIII, і у XIX і на початку XX і в кіниі XX століття. Сьогодні у Львові налічусться 13 ивинтарів, з яких діють чотири. Сьогодні у Львові немає жодного причерковного ивинтаря - ні діючого, ні не діючого. Ми можемо лише вивчати історію і бачити рештки чи залишки колишніх ивинтарів довкола Латинської катедри, костелу Бернардинів та Вірменської церкви.

I ті історичні иеркви, і ті новозбудовані в Галичині є справжніми витворами мистецтва. I кількість новозбудованих храмів вражає. Духовне середовище не мислиться без мистеџького середовища. Духовне середовище, матеріальним втіленням якого є церква, покращується і прикрашається зі застосуванням усіх доступних мистецьких засобів. І це не змінюеться від середньовіччя до сьогодні.

Співіснування цвинтаря і иеркви впродовж століть було дуже тісним. "Мініивинтар" у иерковних криптах $i$ справжній цвинтар навколо иеркви. Сьогодні ия ситуаџія кардинально змінилася. Я не знаю прикладу закладення ивинтаря довкола новозбудованої иеркви. Я також не знаю актуального будівниитва иеркви на новозакладеному цвинтарі чи на відносно новому цвинтарі, який функиіонує і на якому нема церкви. Тобто можна сказати, ио сьогодні церква і цвинтар рухаються до співіснування на відстані.

Така ситуачія характерна для більших міст - динамічніших, які швидко розвиваються і змінюються. Маленькі містечка і села більи схильні до збереження традицій. Якщо в якомусь населеному пункті існує цвинтар коло церкви, то сьогодні ніхто руйнувати його не збирається. Сьогодні люди скоріше з пошаною ставляться і до цвинтаря і до черкви не лише як до інституиії, але і як до споруди.

Ключові слова: ивинтар, иерква, витвір мистецтва, монумент, консервація. 